\title{
Effect of Fluoride and Bentonite on Biochemical Aspects of Oxidative Stress in Pisum sativum L.
}

\author{
Martyna Śnioszek', Arkadiusz Telesiński", Beata Smolik', Helena Zakrzewska \\ 1 Department of Plant Physiology and Biochemistry, West Pomeranian University of Technology in Szczecin, \\ Słowackiego 17, 71-434 Szczecin, Poland \\ * Corresponding author's e-mail: Arkadiusz.Telesinski@zut.edu.pl
}

\begin{abstract}
Fluoride is regarded as one of the strongest oxidants, which causes oxidative changes in cells of living organisms. It may both increase the content of reactive oxygen species and inhibit the activity of antioxidative enzyme. In recent years, many researchers successfully used the properties of clay minerals in the sorption of fluoride ion from water. This raises the question of the possibility of limiting the effect of fluorine on the negative changes in plants by adding bentonite to soil. A two-year pot experiment was carried out in the Greenhouse of West Pomeranian University of Technology in Szczecin, on loamy sand and sandy loam. Each sample of soil was mixed with three different concentrations of bentonite $-1,5,10 \%$ of dry weight (DW) of the soil and then treated with $30 \mathrm{mmol}$ of $\mathrm{F}^{-}$per $1 \mathrm{~kg}$ of dry weight of the soil in a form of $\mathrm{NaF}$ solution. A control series was prepared for each soil, to which no additives were added. The medium prepared in such way was transferred to plastic pots ( $3 \mathrm{~kg}$ each) and seeded with 16 pea seeds of Pisum sativum. In three phases of pea development (4 leaves unfolded, flowering and development of fruit), fresh leaf samples were collected and the concentrations of ascorbic acid, reduced glutathione, total flavonoids and total polyphenols were measured. Sodium fluoride introduced to the soil changed the level of antioxidant parameters in the plant, which may suggest that fluoride is involved in the formation of reactive oxygen species, resulting in oxidative stress. Bentonite in a dosage of $10 \%$ reduced the toxic effects of fluoride on the oxidative balance and morphological changes in the plant, which was observed especially for loamy sand, naturally poor in clay minerals.
\end{abstract}

Keywords: fluoride, bentonite, oxidative stress, antioxidants, Pisum sativum

\section{INTRODUCTION}

In recent years, the emission of fluoride was significantly reduced as a result of new technologies introduced to main emitter of HF [Franzaring et al. 2006]. Some authors still conclude that it is important to monitor the fluoride levels in the environment, especially because the main amount of fluoride comes from natural resources. For example, biomass burning may represent a major source of fluoride, in a form of fine particles which can be transported far away from the emitter [Jayarathne et al. 2016; Weinstein and Davison 2003]. Years of research in fluoride have documented that this element accumulates in plants mostly from air pollution and it is absorbed directly through leaves. Root uptake is definitely insignificant in the air polluted areas. However, plants can incorporate fluoride from contaminated soil as well, especially when highly polluted; for example, from multi-sources and extensive application of phosphate fertilizers [Gautam and Bhardwaj 2010; Jha et al. 2008; Mezghani et al. 2005; Reddy and Kaur 2008].

The natural levels of fluoride in plant leaves ranges between $5-15 \mathrm{mg} \cdot \mathrm{kg}^{-1}$ [Franzaring et al. 2006]. Most of the researchers reported that the level of fluoride in the medium affected the level of fluoride in plant tissues [Gupta et al. 2009; Ruan et al. 2003].

The fluoride contents in soil depend on the mineral composition of inorganic fraction. For example, apatite is the original source of fluoride in soil. Therefore, the clay fraction contains the 
greatest amount of fluoride, whereas the arid soils contain the least [Madhavan and Subramanian 2002; Wang et al. 2002]. According to Hamdi and Srasra [2007], two points are important to enable the F sorption process: the amount of variable charge on the clay and the extent to which the hydroxyl groups may be removed, both dependent on the $\mathrm{pH}$ of soil.

It is well-known that fluoride changes the biochemical homeostasis of oxidative stress in plant cells and the level of ROS [Chakrabarti and Patra 2015]. The present study evaluated the effect of fluoride and bentonite on non-enzymatic antioxidant contents in pea leves: ascorbic acid, reduced glutathione, total flavonoids and total polyphenols.

\section{MATERIAL AND METHODS}

\section{Setting up the experiment}

The two-year pot experiment was carried out on two different kinds of soil, the characteristics of which are presented in the Table 1. The soil samples were taken from the surface layer of arable land at the depth of $0-20 \mathrm{~cm}$ at the Agricultural Experimental Station in Lipnik $\left(53^{\circ} 24^{\prime} \mathrm{N}\right.$, $\left.14^{\circ} 28^{\prime} \mathrm{E}\right)$ and Teaching and Research Center for Renewable Energy in Ostoja $\left(53^{\circ} 41^{\prime} \mathrm{N}, 14^{\circ} 48^{\prime} \mathrm{E}\right)$ situated in the West Pomeranian District, Poland. Loamy sand (LS) and sandy loam (SL) were used in the experiment, respectively.

Soil samples were air-dried and sieved $(2 \mathrm{~mm}$ mesh). Each sample of soil was mixed with three different concentrations of bentonite $-1,5,10 \%$ of dry weight (DW) of the soil and then treated

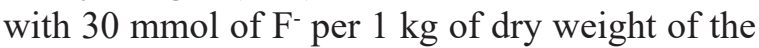
soil in a form of $\mathrm{NaF}$ solution so that the humidity of the three kilograms soil samples was adjusted to $60 \%$ capillary water capacity.

The control samples were prepared using the same procedure by adding just water with no $\mathrm{NaF}$ and bentonite. For each combination, three independent samples were conducted. With the medium prepared in such way, the plastic pots were filled and sowed with pea seeds (Pisum sativum),
16 seeds per each pot. After three days, the pots were moved outdoors under the foil tunnel at the Greenhouse of West Pomeranian University of Technology in Szczecin.

According to $\mathrm{BBCH}$-scale for peas in three phases of development (4 leaves unfolded, flowering and development of fruit), fresh leaf samples were collected and homogenized with buffer to measure the concentration of ascorbic acid (AA), reduced glutathione (GSH), total flavonoid (Flav) and total polyphenol content (Phe).

\section{Determination of antioxidants}

The contents of ascorbic acid (AA) and reduced glutathione (GSH) were determined according to Guri [1983]. The leaf samples (1 g) were homogenized in frozen mortars with 3\% trichloroacetic acid containing $0.5 \mathrm{mM}$ of EDTA$\mathrm{Na}_{2}$ and then centrifuged at $14,800 \mathrm{~g}$ at $4^{\circ} \mathrm{C}$ for 15 minutes. The level of ascorbic acid was measured spectrophotometrically with 2,6-dichlorophenolindophenol (at $600 \mathrm{~nm}$ ) The concentration of AA was calculated from the standard curve and presented as $\mu \mathrm{g} \mathrm{AA} \cdot \mathrm{g}^{-1}$ fw. GSH concentration was measured with DTNB (5,5'-dithiobis(2-nitrobenzoic acid)) which reacts with GSH producing a coloured product. The absorbance of TNB (2-nitro-5-thiobenzoate) was measured at $412 \mathrm{~nm}$. The results were presented as $\mathrm{mg} \mathrm{GSH} \cdot \mathrm{g}^{-1} \mathrm{fw}$.

Flavonoids and polyphenols were extrated with $80 \%$ methanol and then centrifuged at $14,800 \mathrm{~g}$ at $4^{\circ} \mathrm{C}$ for 15 minutes. Determination of total flavonoids content (Flav) was assayed with the method described by Woisky and Salatino [1998] involving $\mathrm{AlCl}_{3}$ which forms stable complex of yellow colour. The absorbance of the complex was measured spectrophotometrically at $420 \mathrm{~nm}$. The results were presented as $\mathrm{mg}$ quercetin $\cdot \mathrm{g}^{-1} \mathrm{fw}$. Total polyphenols content (Phe) was determined by Folin-Ciocalteu method according to [Singleton et al. 1999]. The absorbance was measured at 650 $\mathrm{nm}$ and the total polyphenol concentration was calculated from the standard curve. The results were expressed as $\mathrm{mg}$ of gallic acid equivalent (GAE) per gram of fresh weight of plant tissue.

Table 1. Certain physicochemical properties of soils used in the experiment

\begin{tabular}{|c|c|c|c|c|c|}
\hline Type of soil & $\mathrm{C}_{\text {org }}, \mathrm{g} \cdot \mathrm{kg}^{-1}$ & $\mathrm{~N}_{\text {tot }} \mathrm{g} \cdot \mathrm{kg}^{-1}$ & $\mathrm{pH}_{\mathrm{KCl}}$ & $\mathrm{HAC}, \mathrm{mmol}(+) \cdot \mathrm{kg}^{-1}$ & $\mathrm{EBC}, \mathrm{mmol}(+) \cdot \mathrm{kg}^{-1}$ \\
\hline LS & 8.81 & 0.72 & 6.36 & 13.39 & 10.51 \\
\hline SL & 10.91 & 0.93 & 6.81 & 11.81 & 13.02 \\
\hline
\end{tabular}

LS loamy sand, SL sandy loam, HAC hydrolytic acidity, $\mathrm{N}_{\text {tot }}$ total nitrogen content, $\mathrm{C}_{\text {org }}$ organic carbon content, EBC exchangeable base cations 


\section{Statistical analysis}

All experimental results were statistically analyzed using the STATISTICA 12.5. The data from three measurements $(n=3)$ were analyzed using one-way ANOVA test followed by the post hoc Tukey's test. Differences were considered significant at the $\mathrm{p}<0.05$ level. The results were expressed as mean \pm standard deviation.

\section{RESULTS AND DISCUSSION}

\section{Concentration of reduced glutathione}

In first year of experiment, the concentration of GSH (Table 2) in the pea grown on loamy sand with $30 \mathrm{mmol} \mathrm{F}^{-} \cdot \mathrm{kg}$ and without bentonite was lower than in the control plant for all three phases of development (by 27\%, 4\% and 27\%,respectively). The bentonite added to the soil with
$\mathrm{NaF}$ mostly decreased in the level of GSH in plant tissue if compared to the series with $\mathrm{NaF}$ (no bentonite) and the values were usually lower than in the reference plant. In the second year of the experiment, a similar effect was observed; the fluoride added to the soil reduced the concentration of GSH in the three measurement dates by $18 \%, 27 \%$ and $33 \%$ of control, respectively (Table 2). It was observed that bentonite, especially in a dosage of $10 \%$, caused an increase in GSH concentration, reducing the negative effect of fluoride. In the experiment with sandy loam, a similar tendency was observed for the samples of leaves collected in a very young phase of pea development (in both years of experiment) and in the development of fruit phase in second year of experiment, where the concentration of GSH for the combination with $10 \%$ of bentonite was $39 \%$ higher than in the control. The content of GSH in plant tissues, was usually reduced under the influ-

Table 2. Effect of fluoride and bentonite on GSH concentration in Pisum sativum, mg $\mathrm{GSH} \cdot \mathrm{g}^{-1}$ fw.

\begin{tabular}{|c|c|c|c|c|c|c|c|c|c|}
\hline \multirow{2}{*}{ Treatment } & \multicolumn{9}{|c|}{ Phases of pea development } \\
\hline & \multicolumn{3}{|c|}{4 leaves unfolded } & \multicolumn{3}{|c|}{ Flowering } & \multicolumn{3}{|c|}{ Fruit development } \\
\hline \multicolumn{10}{|c|}{ LS, $1^{\text {st }}$ year } \\
\hline Control & 1,651 & \pm & $0,022 \mathrm{a}$ & 2,422 & \pm & $0,031 \mathrm{~b}$ & 3,423 & \pm & $0,025 a$ \\
\hline $\mathrm{NaF}$ & 1,199 & \pm & $0,007 \mathrm{e}$ & 2,322 & \pm & $0,102 b$ & 2,496 & \pm & $0,013 d$ \\
\hline $\mathrm{NaF}+1 \%$ of bentonite & 1,452 & \pm & $0,038 \mathrm{~b}$ & 2,592 & \pm & $0,025 \mathrm{a}$ & 2,498 & \pm & $0,051 \mathrm{~d}$ \\
\hline $\mathrm{NaF}+5 \%$ of bentonite & 1,392 & \pm & $0,014 \mathrm{c}$ & 2,347 & \pm & $0,025 \mathrm{~b}$ & 2,721 & \pm & $0,039 \mathrm{c}$ \\
\hline $\mathrm{NaF}+10 \%$ of bentonite & 1,321 & \pm & $0,019 d$ & 2,019 & \pm & $0,019 \mathrm{c}$ & 3,030 & \pm & $0,019 \mathrm{~b}$ \\
\hline \multicolumn{10}{|c|}{ LS, $2^{\text {nd }}$ year } \\
\hline Control & 1,306 & \pm & $0,038 a$ & 2,041 & \pm & $0,013 \mathrm{c}$ & 2,449 & \pm & $0,006 \mathrm{c}$ \\
\hline $\mathrm{NaF}$ & 1,163 & \pm & $0,015 b$ & 2,270 & \pm & $0,032 a$ & 2,719 & \pm & $0,032 \mathrm{a}$ \\
\hline $\mathrm{NaF}+1 \%$ of bentonite & 1,153 & \pm & $0,013 b$ & 2,114 & \pm & $0,019 b$ & 2,373 & \pm & $0,007 d$ \\
\hline $\mathrm{NaF}+5 \%$ of bentonite & 1,297 & \pm & $0,019 a$ & 2,053 & \pm & $0,006 \mathrm{c}$ & 2,564 & \pm & $0,032 b$ \\
\hline $\mathrm{NaF}+10 \%$ of bentonite & 1,324 & \pm & $0,000 \mathrm{a}$ & 2,259 & \pm & $0,025 \mathrm{a}$ & 2,710 & \pm & $0,013 \mathrm{a}$ \\
\hline \multicolumn{10}{|c|}{ SL, $1^{\text {st }}$ year } \\
\hline Control & 1,007 & \pm & $0,001 \mathrm{~b}$ & 0,829 & \pm & $0,004 \mathrm{~b}$ & 0,863 & \pm & $0,011 \mathrm{a}$ \\
\hline $\mathrm{NaF}$ & 0,822 & \pm & $0,000 \mathrm{c}$ & 0,609 & \pm & $0,027 d$ & 0,581 & \pm & $0,020 \mathrm{c}$ \\
\hline $\mathrm{NaF}+1 \%$ of bentonite & 0,506 & \pm & $0,000 \mathrm{e}$ & 0,683 & \pm & $0,054 \mathrm{c}$ & 0,698 & \pm & $0,017 \mathrm{~b}$ \\
\hline $\mathrm{NaF}+5 \%$ of bentonite & 0,512 & \pm & $0,000 d$ & 0,983 & \pm & $0,002 a$ & 0,846 & \pm & $0,036 a$ \\
\hline $\mathrm{NaF}+10 \%$ of bentonite & 1,070 & \pm & $0,000 \mathrm{a}$ & 1,003 & \pm & $0,006 a$ & 0,854 & \pm & $0,009 a$ \\
\hline \multicolumn{10}{|c|}{$S L, 2^{\text {nd }}$ year } \\
\hline Control & 0,863 & \pm & $0,004 \mathrm{~b}$ & 1,002 & \pm & $0,017 \mathrm{~b}$ & 0,860 & \pm & $0,026 \mathrm{~b}$ \\
\hline $\mathrm{NaF}$ & 0,768 & \pm & $0,007 \mathrm{c}$ & 1,051 & \pm & $0,030 \mathrm{~b}$ & 0,719 & \pm & $0,009 \mathrm{c}$ \\
\hline $\mathrm{NaF}+1 \%$ of bentonite & 0,707 & \pm & $0,002 d$ & 0,904 & \pm & $0,037 \mathrm{c}$ & 0,724 & \pm & $0,004 \mathrm{c}$ \\
\hline $\mathrm{NaF}+5 \%$ of bentonite & 0,681 & \pm & $0,004 \mathrm{e}$ & 1,147 & \pm & $0,006 a$ & 0,887 & \pm & $0,018 \mathrm{~b}$ \\
\hline $\mathrm{NaF}+10 \%$ of bentonite & 0,888 & \pm & $0,004 a$ & 0,889 & \pm & $0,011 \mathrm{c}$ & 1,192 & \pm & $0,004 a$ \\
\hline
\end{tabular}

Data are expressed as a mean \pm SD of three replicates, different letters for each soil and each year correspond to significant differences at level $\mathrm{p}<0.05$, LS loamy sand, SL sandy loam 
ence of sodium fluoride. In the case of pea growing on sandy loam, an increase in GSH concentration was observed in several analytical terms, compared to the control.

According to many authors, the concentration of glutathione under the influence of various environmental stresses has been reduced. In the pea leaves treated with cadmium chloride, the content of GSH decreased by $50 \%$ compared to the control [Romero-Puertas et al. 2007]. The drop in GSH content in the tissues of pea under the influence of cadmium was also noted by Smiri et al. [2010]. Metwally et al. [2005] observed that pea varieties sensitive to $\mathrm{Cd}$, in contrast to more resistant ones, contained lower concentrations of GSH, which may reduce the plant ability to decrease the stress caused by this element. As reported by Lawson and $\mathrm{Yu}$ [2003], different results like a decrease or increase in GSH content under the influence of $\mathrm{F}^{-}$may be due to the varying conditions of the experiment. The increase in GSH content is probably a consequence of the decrease in $\mathrm{H}_{2} \mathrm{O}_{2}$ production which follows the inhibition of SOD activity by the abovementioned fluoride.

\section{Concentration of ascorbic acid}

A very important parameter in oxidative stress assesment is the level of ascorbic acid. The levels of AA (Table 3) in the tested plant differed depending on the year and the soil type used in the experiment. In first year of experiment, for both types of soil, in first two phases of pea development, the differences in the levels of AA between the series were mainly statistically non-significant. Only during the fruit development period, the influence of $\mathrm{F}^{-}$on AA content was observed: for loamy sand with $\mathrm{NaF}$ treatment, the level of AA increased to $232 \%$ of control, for sandy loam, it decreased to $44 \%$ of control. The bentonite added to the soil in three dosages did not significantly change the effect of $\mathrm{NaF}$ on AA content in most of the cases. In the second year of the experiment, the levels of AA in pea grown in the loamy sand differed from the results obtained in the first year. $\mathrm{NaF}$ applied to the soil increased the concentration of AA up to $150 \%$ of control in the first phase. The bentonite decreased the level of AA inversely proportionally to the dosage of the mineral. In

Table 3. Effect of fluoride and bentonite on AA concentration in Pisum sativum, $\mu \mathrm{g} \mathrm{AA} \cdot \mathrm{g}^{-1} \mathrm{fw}$.

\begin{tabular}{|c|c|c|c|c|c|c|c|c|c|}
\hline \multirow{2}{*}{ Dose of bentonite } & \multicolumn{9}{|c|}{ Phases of pea development } \\
\hline & \multicolumn{3}{|c|}{4 leaves unfolded } & \multicolumn{3}{|c|}{ Flowering } & \multicolumn{3}{|c|}{ Fruit development } \\
\hline \multicolumn{10}{|c|}{ LS, $1^{\text {st }}$ year } \\
\hline Control & 86,24 & \pm & $4,17 \mathrm{a}$ & 75,94 & \pm & $0,00 \mathrm{a}$ & 28,50 & \pm & $7,54 \mathrm{~b}$ \\
\hline $\mathrm{NaF}$ & 84,76 & \pm & $5,50 a$ & 75,77 & \pm & 5,55 a & 66,00 & \pm & $0,00 \mathrm{a}$ \\
\hline $\mathrm{NaF}+1 \%$ of bentonite & 83,36 & \pm & $3,59 \mathrm{a}$ & 72,71 & \pm & $3,60 \mathrm{a}$ & 58,79 & \pm & $14,52 \mathrm{a}$ \\
\hline $\mathrm{NaF}+5 \%$ of bentonite & 68,68 & \pm & $3,58 \mathrm{~b}$ & 73,34 & \pm & $3,63 a$ & 54,94 & \pm & $10,84 \mathrm{a}$ \\
\hline $\mathrm{NaF}+10 \%$ of bentonite & 76,12 & \pm & $0,00 a b$ & 78,07 & \pm & 5,54 a & 50,97 & \pm & $3,59 a b$ \\
\hline \multicolumn{10}{|c|}{$L S, 2^{\text {nd }}$ year } \\
\hline Control & 78,37 & \pm & $5,47 a$ & 83,04 & \pm & 8,39 a & 65,93 & \pm & $3,62 \mathrm{a}$ \\
\hline $\mathrm{NaF}$ & 78,29 & \pm & $2,07 \mathrm{a}$ & 82,33 & \pm & $2,08 \mathrm{a}$ & 51,48 & \pm & $10,88 a b$ \\
\hline $\mathrm{NaF}+1 \%$ of bentonite & 76,37 & \pm & $3,60 \mathrm{a}$ & 84,35 & \pm & $0,00 \mathrm{a}$ & 36,99 & \pm & $3,63 \mathrm{~b}$ \\
\hline $\mathrm{NaF}+5 \%$ of bentonite & 78,16 & \pm & $2,10 \mathrm{a}$ & 63,45 & \pm & $4,18 b$ & 60,80 & \pm & $4,16 \mathrm{a}$ \\
\hline $\mathrm{NaF}+10 \%$ of bentonite & 70,05 & \pm & $2,07 \mathrm{a}$ & 64,17 & \pm & $9,04 \mathrm{~b}$ & 63,50 & \pm & $2,09 \mathrm{a}$ \\
\hline \multicolumn{10}{|c|}{$\mathrm{SL}, 1^{\text {st }}$ year } \\
\hline Control & 168,43 & \pm & $5,62 \mathrm{a}$ & 111,98 & \pm & $2,30 \mathrm{e}$ & 95,01 & \pm & $2,15 b$ \\
\hline $\mathrm{NaF}$ & 252,97 & \pm & $0,77 \mathrm{~b}$ & 119,26 & \pm & $0,00 \mathrm{~d}$ & 7,63 & \pm & $1,56 \mathrm{~d}$ \\
\hline $\mathrm{NaF}+1 \%$ of bentonite & 230,83 & \pm & $1,95 \mathrm{c}$ & 152,57 & \pm & $0,00 \mathrm{a}$ & 69,86 & \pm & $3,06 \mathrm{c}$ \\
\hline $\mathrm{NaF}+5 \%$ of bentonite & 203,54 & \pm & $0,39 \mathrm{~d}$ & 128,69 & \pm & $1,01 \mathrm{c}$ & 71,16 & \pm & $0,97 \mathrm{c}$ \\
\hline $\mathrm{NaF}+10 \%$ of bentonite & 161,34 & \pm & 5,27 a & 146,46 & \pm & $2,13 \mathrm{~b}$ & 108,13 & \pm & $0,39 a$ \\
\hline \multicolumn{10}{|c|}{$\mathrm{SL}, 2^{\text {nd }}$ year } \\
\hline Control & 158,93 & \pm & $3,19 a$ & 91,65 & \pm & $1,80 \mathrm{c}$ & 108,18 & \pm & $2,33 \mathrm{c}$ \\
\hline $\mathrm{NaF}$ & 156,67 & \pm & $1,55 a$ & 94,63 & \pm & $2,74 \mathrm{c}$ & 107,85 & \pm & $1,95 \mathrm{c}$ \\
\hline $\mathrm{NaF}+1 \%$ of bentonite & 128,02 & \pm & $2,72 \mathrm{~b}$ & 110,23 & \pm & $0,97 \mathrm{~b}$ & 97,57 & \pm & $1,95 \mathrm{~d}$ \\
\hline $\mathrm{NaF}+5 \%$ of bentonite & 153,03 & \pm & $3,68 \mathrm{a}$ & 115,15 & \pm & $1,54 \mathrm{~b}$ & 131,42 & \pm & $1,80 \mathrm{~b}$ \\
\hline $\mathrm{NaF}+10 \%$ of bentonite & 152,10 & \pm & $0,20 a$ & 122,16 & \pm & $1,95 \mathrm{a}$ & 154,46 & \pm & $2,35 \mathrm{a}$ \\
\hline
\end{tabular}

Data are expressed as a mean \pm SD of three replicates, different letters for each soil and each year correspond to significant differences at level $\mathrm{p}<0.05$, LS loamy sand, SL sandy loam 
the flowering phase, it was difficult to notice any tendency, while in the fruit development phase the addition of $\mathrm{NaF}$ decreased the level of AA by $92 \%$ of control, and the mineral added to the soil, especially in the dosage of $10 \%$, decreased the level of AA in the plant up to $114 \%$ of control. In the second year of experiment, for the series with sandy loam, $\mathrm{NaF}$ did not cause an increase in AA level, but only $\mathrm{NaF}$ with a combination with bentonite $(5,10 \%)$ enhanced the AA concentration in the second and third measured phase.

Bhargava and Bhardwaj [2010] observed that the level of AA in seedlings of wheat (Triticuam aestivum) initially decreased and then increased proportionaly to the level of fluoride in the medium. In the studies conducted by Gupta et al. [2009], the content of ascorbic acid in rice (Oryza sativa) growing in $\mathrm{NaF}$ solutions was lower than in the control plants, but increased along with the concentration of $\mathrm{NaF}$ introduced into the medium. The authors explained that $\mathrm{F}^{-}$inhibits the ascorbate oxidase activity and that it is associated with inhibition of AA degradation. The drop in AA and DHA content in peas may also be caused by AA oxidation by $\mathrm{H}_{2} \mathrm{O}_{2}$ and degradation of DHA [Jimenez et al. 1998].

In this study, the content of AA in plant growing in sandy loam did not differ to a large extent from the control. In turn, in the experiment with loamy sand, the results obtained depended on the year of research, which suggests that the weather conditions might also affect the AA content. As observed by Garcia-Plazaola et al. [2003], a drop in temperature might cause an increase in the content of hydrophilic antioxidants in plants. Under oxidative stress, when the capacity of the regeneration system is exceeded, the AA pool can also be reduced [Foyer et al. 1994].

\section{Total polyphenol and total flavonoids concentration}

In the pot experiment carried out in first year on the loamy sand, the contents of Phe in the pea treated with $\mathrm{NaF}$, in the phase of 4 leaves unfolded and fruit development, were lower than in the control plants by approximately $10 \%$, while in the flowering phase - higher by $15 \%$ (Table 4 ). In the first phase, the addition of $10 \%$ of bentonite increased the Phe concentration to $118 \%$ of control. In the flowering phase it was difficult to draw a clear conclusion, as the concentration of Phe increased with the increase of $\mathrm{NaF}$ and the addition of the bentonite in the amount of $10 \%$ caused the decrease in Phe concentration by $8 \%$. In the phase of fruit development, $1 \%$ of bentonite added to the soil with $\mathrm{NaF}$ increased the level of Phe to $106 \%$ of control. In the experiment with sandy loam, in the phase of 4 leaves unfolded, the concentration of Phe in the series with $\mathrm{NaF}$ but no bentonite was lower than in the control by $13 \%$. In the series with bentonite, the concentrations of Phe were higher than in the control and reached $127 \%$ (10\% bentonite series). In the phase of flowering, the change in the concentration of total polyphenols was observed only for the series with $\mathrm{F}^{-}$and $1 \%$ bentonite (by $25 \%$ ) and $10 \%$ bentonite (by $10 \%$ ), compared to the control. In the phase of fruit development in each series with $\mathrm{NaF}$, the content of Phe was higher than in the control. The highest increase of the measured parameter was observed in plants growing in the soil with $\mathrm{NaF}$ and bentonite in dosages of $5 \%$ and $10 \%$, by $28 \%$ and $25 \%$, respectively, compared to the control.

In the second year of experiment, for the plants grown on loamy sand, the concentration of total polyphenols clearly depended on the dosage of $\mathrm{NaF}$ and bentonite. Fluoride added to the soil caused the decrease in Phe concentration, in each three phases, by $8 \%, 11 \%$ and $31 \%$, respectively, compared to the control. Bentonite in the dosages of $5 \%$ and $10 \%$ influenced the increase of Phe concentration up to approximately $100 \%$ of the control, in comparison to the series with $\mathrm{NaF}$ but no bentonite. In the plant growing on sandy loam, the content of Phe in the phase of 4 leaves unfolded, increased by $25 \%$ for the $\mathrm{NaF}$ treated plant. Bentonite in the dosage of $1 \%$, caused a decrease in Phe concentration. The highest increase of Phe level was observed for the series with $10 \%$ of bentonite (by $40 \%$ ). In the phase of flowering, in the series with $\mathrm{NaF}$ only, and $\mathrm{NaF}$ with $1 \%$ or $10 \%$ of bentonite, the Phe content was similar to control concentrations, while in $5 \%$ of bentonite series the Phe concentration was lower than in the control. In the phase of fruit development, the Phe content decreased to $86 \%$ of control. Bentonite applied to the soil in three dosages influenced the increase in the concentration of Phe even up to $114 \%$ of control (series with $5 \%$ of bentonite).

The next measured parameter was flavonoids content. In the first year of experiment, the concentration of total flavonoids for the plants grown on loamy sand in the phase of 4 leaves unfolded, was $110 \%$ of control. In the series with $\mathrm{NaF}$ and bentonite, the level of this parameter dropped 
Table 4. Effect of fluoride and bentonite on Phe concentration in Pisum sativum, $\mathrm{mg}$ of GAE $\cdot \mathrm{g}^{-1} \mathrm{fw}$.

\begin{tabular}{|c|c|c|c|c|c|c|c|c|c|}
\hline \multirow{2}{*}{ Dose of bentonite } & \multicolumn{9}{|c|}{ Phases of pea development } \\
\hline & \multicolumn{3}{|c|}{4 leaves unfolded } & \multicolumn{3}{|c|}{ Flowering } & \multicolumn{3}{|c|}{ Fruit development } \\
\hline \multicolumn{10}{|c|}{ LS, $1^{\text {st }}$ year } \\
\hline Control & 1,025 & \pm & $0,021 \mathrm{~b}$ & 0,874 & \pm & $0,031 \mathrm{~b}$ & 1,205 & \pm & $0,033 b$ \\
\hline $\mathrm{NaF}$ & 0,930 & \pm & $0,004 \mathrm{c}$ & 1,005 & \pm & $0,017 \mathrm{a}$ & 1,065 & \pm & $0,004 \mathrm{c}$ \\
\hline $\mathrm{NaF}+1 \%$ of bentonite & 0,914 & \pm & $0,013 \mathrm{c}$ & 0,934 & \pm & $0,006 \mathrm{~b}$ & 1,277 & \pm & $0,000 \mathrm{a}$ \\
\hline $\mathrm{NaF}+5 \%$ of bentonite & 0,903 & \pm & $0,021 \mathrm{c}$ & 1,041 & \pm & $0,004 a$ & 1,185 & \pm & $0,012 b$ \\
\hline $\mathrm{NaF}+10 \%$ of bentonite & 1,212 & \pm & $0,031 \mathrm{a}$ & 0,805 & \pm & $0,039 \mathrm{c}$ & 1,212 & \pm & $0,013 b$ \\
\hline \multicolumn{10}{|c|}{ LS, $2^{\text {nd }}$ year } \\
\hline Control & 0,913 & \pm & $0,010 \mathrm{~b}$ & 0,948 & \pm & $0,010 \mathrm{c}$ & 1,167 & \pm & $0,020 \mathrm{c}$ \\
\hline $\mathrm{NaF}$ & 0,795 & \pm & $0,021 \mathrm{~d}$ & 0,952 & \pm & $0,010 \mathrm{c}$ & 1,314 & \pm & $0,073 b$ \\
\hline $\mathrm{NaF}+1 \%$ of bentonite & 0,845 & \pm & $0,016 \mathrm{c}$ & 1,184 & \pm & $0,011 \mathrm{a}$ & 1,297 & \pm & $0,006 \mathrm{~b}$ \\
\hline $\mathrm{NaF}+5 \%$ of bentonite & 0,881 & \pm & $0,015 \mathrm{bc}$ & 0,942 & \pm & $0,060 \mathrm{c}$ & 1,489 & \pm & $0,010 a$ \\
\hline $\mathrm{NaF}+10 \%$ of bentonite & 1,150 & \pm & $0,023 \mathrm{a}$ & 1,037 & \pm & $0,019 \mathrm{~b}$ & 1,457 & \pm & $0,015 a$ \\
\hline \multicolumn{10}{|c|}{ SL, $1^{\text {st }}$ year } \\
\hline Control & 1,584 & \pm & $0,021 \mathrm{c}$ & 2,179 & \pm & $0,068 \mathrm{a}$ & 2,462 & \pm & $0,121 \mathrm{a}$ \\
\hline $\mathrm{NaF}$ & 1,460 & \pm & $0,050 \mathrm{~d}$ & 1,941 & \pm & $0,017 \mathrm{~b}$ & 1,711 & \pm & $0,004 \mathrm{c}$ \\
\hline $\mathrm{NaF}+1 \%$ of bentonite & 1,630 & \pm & $0,027 \mathrm{bc}$ & 1,702 & \pm & $0,002 \mathrm{c}$ & 1,538 & \pm & $0,063 \mathrm{c}$ \\
\hline $\mathrm{NaF}+5 \%$ of bentonite & 1,703 & \pm & $0,006 \mathrm{~b}$ & 1,876 & \pm & $0,057 \mathrm{~b}$ & 2,060 & \pm & $0,008 \mathrm{~b}$ \\
\hline $\mathrm{NaF}+10 \%$ of bentonite & 1,868 & \pm & $0,023 a$ & 2,105 & \pm & $0,008 \mathrm{a}$ & 2,223 & \pm & $0,054 \mathrm{~b}$ \\
\hline \multicolumn{10}{|c|}{ SL, $2^{\text {nd }}$ year } \\
\hline Control & 1,972 & \pm & $0,034 \mathrm{c}$ & 2,232 & \pm & $0,011 \mathrm{ab}$ & 2,206 & \pm & $0,027 \mathrm{c}$ \\
\hline $\mathrm{NaF}$ & 2,456 & \pm & $0,074 \mathrm{~b}$ & 2,321 & \pm & $0,031 \mathrm{a}$ & 1,906 & \pm & $0,039 \mathrm{e}$ \\
\hline $\mathrm{NaF}+1 \%$ of bentonite & 2,023 & \pm & $0,006 \mathrm{c}$ & 2,337 & \pm & $0,067 \mathrm{a}$ & 2,002 & \pm & $0,004 \mathrm{~d}$ \\
\hline $\mathrm{NaF}+5 \%$ of bentonite & 2,342 & \pm & $0,002 \mathrm{~b}$ & 2,056 & \pm & $0,045 \mathrm{c}$ & 2,526 & \pm & $0,033 a$ \\
\hline $\mathrm{NaF}+10 \%$ of bentonite & 2,757 & \pm & $0,056 \mathrm{a}$ & 2,181 & \pm & $0,006 \mathrm{~b}$ & 2,443 & \pm & $0,012 b$ \\
\hline
\end{tabular}

Data are expressed as a mean \pm SD of three replicates, different letters for each soil and each year correspond to significant differences at level $\mathrm{p}<0.05$, LS loamy sand, SL sandy loam

compared to the control, reaching the lowest values for the soil with $\mathrm{NaF}$ and $5 \%$ of bentonite. In the phase of flowering, all the series were characterized by lower concentration of Flav than the control plant with the lowest level in the series with $\mathrm{NaF}$ and no bentonite and $\mathrm{NaF}$ with $5 \%$ of bentonite. In the last phase of development, the observed concentration of Flav differed statistically from the control only for the series with $\mathrm{NaF}$ and bentonite $1 \%$ (decrease by $17 \%$ ) and $5 \%$ (increase by $8 \%$ ).

For the pots with sandy loam (in first year of experiment), in the all stages of plant development, the highest level of Flav was observed for the plants grown with $\mathrm{NaF}$ but without bentonite. The application of the mineral to the soil effected in an increase of Flav level. In each period of analyses, the level of Flav depended on the bentonite dosage. In the first and third period of analyses, the level of measured parameter was closest to the control for the following series: $\mathrm{NaF}$ with $1 \%$ bentonite and $5 \%$ bentonite, while in the third period - only for $5 \%$ of bentonite.
In the second year of experiment, for loamy sand series, the increase of Flav level in comparison to the control was observed in all three stages of development (the increase was approximately by $18-32 \%$ ). The bentonite added to the soil with $\mathrm{NaF}$, may have reduced the influence of $\mathrm{F}^{-}$especially in the second and third period of analyses. be The $10 \%$ dosage of bentonite seemed to be the most effective, because the level of Flav for this series was the closest to the control $(91 \%, 112 \%$ and $105 \%$ of control, respectively for each phase of development). In the series with sandy loam, similar reactions were observed for the 4 leaves unfolded phase. However, different relations were noted for the flowering (the Flav concentration increased by $20 \%$ of control for the series with $\mathrm{NaF}$, no bentonite). The levels of Flav for the series with $\mathrm{NaF}$ and three dosages of bentonite reached $114 \%, 126 \%$ and $109 \%$ of control, respectively.

The level of total polyphenols and total flavonoids in plants seems to be very important in the assessment of oxidative stress. Many papers report antioxidative functions of these compounds 
Table 5. Effect of fluoride and bentonite on Flav concentration in Pisum sativum, mg quercitine $\cdot \mathrm{g}^{-1}$ fw.

\begin{tabular}{|c|c|c|c|c|c|c|c|c|c|}
\hline \multirow{2}{*}{ Dose of bentonite } & \multicolumn{9}{|c|}{ Phases of pea development } \\
\hline & \multicolumn{3}{|c|}{4 leaves unfolded } & \multicolumn{3}{|c|}{ Flowering } & \multicolumn{3}{|c|}{ Fruit development } \\
\hline \multicolumn{10}{|c|}{ LS, $1^{\text {st }}$ year } \\
\hline Control & 2,190 & \pm & $0,013 \mathrm{~b}$ & 3,106 & \pm & $0,007 \mathrm{a}$ & 2,265 & \pm & $0,027 \mathrm{~b}$ \\
\hline $\mathrm{NaF}$ & 2,401 & \pm & $0,009 a$ & 2,634 & \pm & $0,013 b$ & 2,267 & \pm & $0,008 \mathrm{~b}$ \\
\hline $\mathrm{NaF}+1 \%$ of bentonite & 2,123 & \pm & $0,011 \mathrm{c}$ & 1,986 & \pm & $0,021 \mathrm{~d}$ & 1,890 & \pm & $0,002 \mathrm{c}$ \\
\hline $\mathrm{NaF}+5 \%$ of bentonite & 1,821 & \pm & $0,017 \mathrm{e}$ & 2,659 & \pm & $0,006 \mathrm{~b}$ & 2,452 & \pm & $0,013 a$ \\
\hline $\mathrm{NaF}+10 \%$ of bentonite & 2,056 & \pm & $0,010 \mathrm{~d}$ & 2,445 & \pm & $0,002 \mathrm{c}$ & 2,290 & \pm & $0,024 \mathrm{~b}$ \\
\hline \multicolumn{10}{|c|}{ LS, $2^{\text {nd }}$ year } \\
\hline Control & 1,948 & \pm & $0,018 \mathrm{~b}$ & 2,525 & \pm & $0,010 \mathrm{~b}$ & 2,543 & \pm & $0,068 \mathrm{a}$ \\
\hline $\mathrm{NaF}$ & 1,860 & \pm & $0,021 c$ & 2,447 & \pm & $0,016 \mathrm{~d}$ & 2,265 & \pm & $0,018 \mathrm{c}$ \\
\hline $\mathrm{NaF}+1 \%$ of bentonite & 2,022 & \pm & $0,006 a$ & 2,482 & \pm & $0,010 \mathrm{c}$ & 2,489 & \pm & $0,028 \mathrm{a}$ \\
\hline $\mathrm{NaF}+5 \%$ of bentonite & 2,044 & \pm & $0,017 \mathrm{a}$ & 2,532 & \pm & $0,017 \mathrm{~b}$ & 2,411 & \pm & $0,086 a b$ \\
\hline $\mathrm{NaF}+10 \%$ of bentonite & 1,883 & \pm & $0,004 \mathrm{c}$ & 2,698 & \pm & $0,004 \mathrm{a}$ & 2,297 & \pm & $0,023 b c$ \\
\hline \multicolumn{10}{|c|}{$\mathrm{SL}, 1^{\text {st }}$ year } \\
\hline Control & 2,728 & \pm & $0,092 \mathrm{a}$ & 2,285 & \pm & $0,111 \mathrm{~b}$ & 2,737 & \pm & $0,004 \mathrm{~b}$ \\
\hline $\mathrm{NaF}$ & 2,045 & \pm & $0,043 d$ & 1,868 & \pm & $0,033 c$ & 1,700 & \pm & $0,003 \mathrm{e}$ \\
\hline $\mathrm{NaF}+1 \%$ of bentonite & 2,255 & \pm & $0,002 \mathrm{c}$ & 1,412 & \pm & $0,011 d$ & 1,929 & \pm & $0,004 d$ \\
\hline $\mathrm{NaF}+5 \%$ of bentonite & 2,179 & \pm & $0,054 \mathrm{~cd}$ & 2,697 & \pm & $0,015 a$ & 2,330 & \pm & $0,030 \mathrm{c}$ \\
\hline $\mathrm{NaF}+10 \%$ of bentonite & 2,471 & \pm & $0,011 \mathrm{~b}$ & 2,555 & \pm & $0,025 a$ & 2,876 & \pm & $0,010 \mathrm{a}$ \\
\hline \multicolumn{10}{|c|}{$\mathrm{SL}, 2^{\text {nd }}$ year } \\
\hline Control & 2,773 & \pm & $0,030 \mathrm{~b}$ & 2,702 & \pm & $0,001 \mathrm{e}$ & 3,212 & \pm & $0,013 b$ \\
\hline $\mathrm{NaF}$ & 2,693 & \pm & $0,008 \mathrm{c}$ & 3,247 & \pm & $0,013 \mathrm{~b}$ & 2,861 & \pm & $0,007 \mathrm{c}$ \\
\hline $\mathrm{NaF}+1 \%$ of bentonite & 2,787 & \pm & $0,021 \mathrm{~b}$ & 3,074 & \pm & $0,015 \mathrm{c}$ & 2,620 & \pm & $0,007 d$ \\
\hline $\mathrm{NaF}+5 \%$ of bentonite & 3,076 & \pm & $0,048 a$ & 3,398 & \pm & $0,006 \mathrm{a}$ & 3,513 & \pm & $0,008 a$ \\
\hline $\mathrm{NaF}+10 \%$ of bentonite & 2,652 & \pm & $0,007 \mathrm{c}$ & 2,945 & \pm & $0,028 d$ & 3,493 & \pm & $0,017 \mathrm{a}$ \\
\hline
\end{tabular}

Data are expressed as a mean \pm SD of three replicates, different letters for each soil and each year correspond to significant differences at level $\mathrm{p}<0.05$, LS loamy sand, SL sandy loam

[Perez et al. 2002; Yamasaki et al. 1997]. In our study, a decrease in the total polyphenol content (Phe) was observed in pea growing in loamy sand under the influence of $30 \mathrm{mmol} \mathrm{F}{ }^{-} \mathrm{kg}^{-1}$ s.m. soil. In the experiment with light clay, the Phe content, in most analytical terms, was higher in the plants treated with $\mathrm{NaF}$ compared to the control plants. The content of flavonoids in pea leaves differed slightly. Flav content generally decreased in the plants treated with sodium fluoride, for both experiments (with loamy sand and sandy loam).

There are very few reports on the effect of sodium fluoride on the polyphenol content in a plant. Most of the studies concern tea plant, which is a source of both polyphenols and fluorides in human diet. While studying the effect of $\mathrm{F}^{-}$on the Phe content in tea leaves, $\mathrm{Li}$ and $\mathrm{Ni}$ [2009] observed an inversely proportional decrease in the concentration of polyphenols to the dose of $\mathrm{F}^{-}$, which confirms the study of $\mathrm{Lu}$ et al. [2004]. Reddy and Kaur [2008] observed an increase in the content of anthocyanins un- der the influence of $\mathrm{NaF}$ and they explained that anthocyanins might be involved in scavenging reactive oxygen species which resulted from the toxic effects of sodium fluoride.

\section{CONCLUSIONS}

1. Fluoride added to soil disturbed the oxidative balance in plants, which resulted in statisctically significant changes in the level of AA, GSH, Flav and Phe in Pisum sativum, compared to the reference plant.

2. Bentonite added to soil may reduce a toxic effect of $\mathrm{NaF}$ and improve the conditions for plant development. The plants grown in sandy soil reacted especialy positively to $5 \%$ and $10 \%$ of bentonite.

\section{Acknowledgments}

This research was funded by the National Science Center of Poland, No. N N305 385138. 


\section{REFERENCES}

1. Bhargava D., Bhardwaj, N. 2010. Effect of sodium fluoride on seed germination and seedlings growth of Triticum aestivum var. raj. 4083. Journal of Phytology 2 (4), 41-43.

2. Chakrabarti S., Patra P.K. 2015. Biochemical and antioxidant responses of paddy (Oryza sativa L.) to fluoride stress. Fluoride 48 (1), 56-61.

3. Foyer C.H., Descourvieres P., Kunert K.J. 1994. Protection against oxygen radicals - an important defense-mechanism studied in transgenic plants. Plant Cell and Environment 17 (5), 507-523.

4. Franzaring J., Hrenn H., Schumm C., Kiumpp A., Fangmeier A. 2006. Environmental monitoring of fluoride emissions using precipitation, dust, plant and soil samples. Environmental Pollution 144 (1), 158-165.

5. Garcia-Plazaola J.I., Olano J.M., Hernandez A., Becerril J.M. 2003. Photoprotection in evergreen Mediterranean plants during sudden periods of intense cold weather. Trees-Structure and Function 17 (4), 285-291.

6. Gautam R., Bhardwaj N. 2010. Bioaccumulation of fluoride in different plant parts of Hordeum vulgare (barley) var. Rd-2683 from irrigation water. Fluoride 43 (1), 57-60.

7. Gupta S., Banerjee S., Mondal S. 2009. Phytotoxicity of fluoride in the germination of paddy (Oryza sativa) and its effect on the physiology and biochemistry of germinated seedlings. Fluoride 42 (2), 142-146.

8. Guri A. 1983. Variation in glutathione and ascorbic-acid content among selected cultivars of Phaseolus vulgaris prior to and after exposure to ozone. Canadian Journal of Plant Science 63 (3), 733-737.

9. Hamdi N., Srasra E. 2007. Removal of fluoride from acidic wastewater by clay mineral: Effect of solidliquid ratios. Desalination 206 (1-3), 238-244.

10. Jayarathne T., Sultan, C.M., Lee C., Malfatti F., Cox J.L., Pendergraft M.A., Moore K.A., Azam F., Tivanski A.V., Cappa C.D., Bertram T.H., Grassian V.H., Prather K.A., Stone E.A. 2016. Enrichment of saccharides and divalent cations in sea spray aerosol during two phytoplankton blooms. Environmental Science and Technology 50 (21), 11511-11520.

11. Jha S.K., Nayak A.K., Sharma Y.K. 2008. Response of spinach (Spinacea oleracea) to the added fluoride in an alkaline soil. Food and Chemical Toxicology 46 (9), 2968-2971.

12. Jimenez A., Hernandez J.A., Pastori G., del Rio L.A., Sevilla F. 1998. Role of the ascorbate-glutathione cycle of mitochondria and peroxisomes in the senescence of pea leaves. Plant Physiology 118 (4), 1327-1335.

13. Lawson P.B., Yu M.H. 2003. Fluoride inhibition of superoxide dismutase (SOD) from the earthworm Eisenia fetida. Fluoride 36 (3), 143-151.
14. Li C.L., Ni D.J. 2009. Effect of fluoride on chemical constituents of tea leaves. Fluoride 42 (3), 237-243.

15. Lu Y., Guo W.F., Yang, X.Q. 2004. Fluoride content in tea and its relationship with tea quality. Journal of Agricultural and Food Chemistry 52 (14), 4472-4476.

16. Madhavan N., Subramanian V. 2002. Fluoride in fractionated soil samples of Ajmer district, Rajasthan. Journal of Environmental Monitoring 4 (6), 821-822.

17. Metwally A., Safronova V.I., Belimov A.A., Dietz K.J. 2005. Genotypic variation of the response to cadmium toxicity in Pisum sativum. Journal of Experimental Botany 56 (409), 167-178.

18. Mezghani I., Elloumi N., Abdallah F.B., Chaieb M., Boukhris M. 2005. Fluoride accumulation by vegetation in the vicinity of a phosphate fertilizer plant in Tunisia. Fluoride 38 (1), 69-75.

19. Perez F.J., Villegas D., Mejia N. 2002. Ascorbic acid and flavonoid-peroxidase reaction as a detoxifying system of $\mathrm{H} 2 \mathrm{O} 2$ in grapevine leaves. Phytochemistry 60 (6), 573-580.

20. Reddy M.P., Kaur M. 2008. Sodium fluoride induced growth and metabolic changes in Salicornia brachiata Roxb. Water Air and Soil Pollution 188 (1-4), 171-179.

21. Romero-Puertas M.C., Corpas F.J., Rodriguez-Serrano M., Gomez M., del Rio L.A., Sandalio L.M. 2007. Differential expression and regulation of antioxidative enzymes by cadmium in pea plants. Journal of Plant Physiology 164 (10), 1346-1357.

22. Ruan J.Y., Ma L.F., Shi Y.Z., Han W.Y. 2003. Uptake of fluoride by tea plant (Camellia sinensis L.) and the impact of aluminium. Journal of the Science of Food and Agriculture 83 (13), 1342-1348.

23. Singleton V.L., Orthofer R., Lamuela-Raventos R.M. 1999. Analysis of total phenols and other oxidation substrates and antioxidants by means of Folin-Ciocalteu reagent. Oxidants and Antioxidants, Pt A 299, 152-178.

24. Smiri M., Chaoui A., Rouhier N., Kamel C., Gelhaye E., Jacquot J.P., El Ferjani E. 2010. Cadmium induced mitochondrial redox changes in germinating pea seed. Biometals 23 (6), 973-984.

25. Wang W.Y., Li R.B., Tan J.A., Luo K.L., Yang L.S., Li H.R., Li Y.H. 2002. Adsorption and leaching of fluoride in soils of China. Fluoride 35 (2), 122-129.

26. Weinstein L.H., Davison A.W. 2003. Native plant species suitable as bioindicators and biomonitors for airborne fluoride. Environmental Pollution 125 (1), 3-11.

27. Woisky R.G., Salatino A. 1998. Analysis of propolis: some parameters and procedures for chemical quality control. Journal of Apicultural Research 37 (2), 99-105.

28. Yamasaki H., Sakihama Y., Ikehara N. 1997. Flavonoid-peroxidase reaction as a detoxification mechanism of plant cells against $\mathrm{H}_{2} \mathrm{O}_{2}$. Plant Physiology 115 (4), 1405-1412. 